\section{Numerical Simulation of a Site Response Analysis with STRATA Software}

\section{Ana Nicuță, Alexandra Alisa Găină*}

"Gheorghe Asachi" Technical University, Faculty of Civil Engineering and Building Services 43 D. Mangeron, 700050 lași, Romania

*Corresponding author: alisa.gaina@yahoo.com

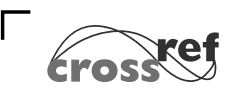
http://dx.doi.org/10.5755/j01.sace.9.4.7129
The analysis of the ground foundation must take into consideration two main aspects: a simulation of the ground motion as close as possible to reality and the correlation of the ground motion with existing geological conditions. Thus, it can be distinguished two main functions of the soils: the function of a dynamic filter for the seismic movement that come from the source, and the function of a deformable spring for the buildings whose support is.

In this paper, the behavior of a site was analyzed from the site response point of view, using different accelerograms of Romanian's earthquake. These accelerograms were recorded during the 1977, 1986 and 1990 earthquakes. In order to perform equivalent linear site response analysis we use the STRATA software for a homogeneous soil layer with more than 10 meters depth. The soil type and the velocity layering were considered constant on the entire soil deposit. The analysis was done both on cohesive and cohesionless soils. The final results have been mapped in terms of soil dynamic characteristics, accelerograms and acceleration response spectrum, under different earthquake excitations.

KEYWORDS: accelerograms, earthquake, site response, soil dynamic, Strata.

Romania is one of the European countries with intense seismic activity. Over the time, the country was shaken by several earthquakes, the majority of them having the epicentral in Vrancea, by far the most seismically active zone of Romania (Vlad and Vlad 2008).

Three major earthquakes that occurred in Vrancea had a considerable impact both on the population and on the buildings. These earthquakes are: March 4, 1977 Vrancea earthquake with $M_{G-R}=7.2$ magnitude (Pomonis, Coburn and Ledbetter 1990), being the first strong seismic motion recorded in Romania, August 31, 1986 with $\mathrm{M}_{\mathrm{G}-\mathrm{R}}=7.0$ magnitude and May 30, $1990\left(\mathrm{M}_{\mathrm{G}-\mathrm{R}}=6.7\right)$, and May 31, $1990\left(\mathrm{M}_{\mathrm{G}-\mathrm{R}}=6.1\right)$ (Balan et al. 1983, Sokolov, Boese and Wenyel 2008, Vlad and Vlad 2008). March 4, 1977 earthquake is considered to be, because of its effects, one of the most devastating seismic shocks occurred in Romania. There were recorded victims and important material loss, especially in the urban centres with high population density and constructions, the majority of them in the south country. The reinstatement in exploitation conditions of the building, as soon as possible, involved high financial efforts. After 1986 and 1990 earthquake no material damage

\section{Introduction}

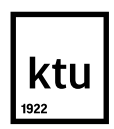

Journal of Sustainable Architecture and Civil Engineering Vol. 4 / No. 9 / 2014 pp. $83-90$

DOI 10.5755/j01.sace.9.4.7129 (C) Kaunas University of Technology 
and victims were recorded. Due to this records obtained during this earthquakes it was possible to define the main characteristics of the Romania seismicity and to draw seismic maps with acceleration distribution for the entire territory.

Concerns regarding anti-seismic insurance appeared with the population growth centres in seismic areas, with the increase in volume and height of the important constructions. The prevention of urban centres decline and reduction of the city expansion are current issues in many states. In order to prevent the occupation of new sites, the engineers have as principal purpose to increase the building's service life through flexibility and adaptability, and to renovate the existing buildings with design to grow their lifetime (Mahin 2008).

Because of these aspects mentioned above, it is required to take into consideration, in designing a new building, the impact on the environment. The concept of sustainable design or so-called green buildings is based on lower consumption and protection of the environment. This concept applied on earthquake engineering design implies other aspects like durability, longevity, efficient design methods and efficient structural methods.

Recently, on the Romanian territory large numbers of earthquakes was recorded with small and moderate intensity. This high seismic activity, which in a first stage induces a positive effect on the compaction of the ground surface, can also have negative effects regarding the subsequent stresses and strains, which affect primarily the mechanical characteristics, thus their resistance.

Therefore, the necessity of knowing the behaviour of the soil subjected to dynamic loads is required under the conditions mentioned above. The present paper aims to develop a numerical simulation of horizontally layered soil deposits (cohesive and cohesionless), to a depth up to $100 \mathrm{~m}$, in order to evaluate soil effects under different earthquake excitations. An equivalent linear site response analysis is performed by using Strata software.

Input data for the site response analysis

In Romania, the design of structures for earthquake excitation is based on Eurocode 8 and Romanian designing code P100/2013. These norms give some general elements regarding the seismic effects on sites recorded during the time. In relation to the average shear waves in the first $30 \mathrm{~m}$, according with EC 8 first part, the soils are classified in five categories $A, B, C, D$ and $E$ (Eurocode 8 1998)

For the response spectrum analysis of a site it is necessary to highlight the dynamic characteristics of the studied soil, namely stiffness and material damping. Soil stiffness is characterized by wave velocity $\left(V_{s}\right)$ or shear modulus (G) (Zhang, Andrus and Juang 2005).

Through previous studies were able to estimate the dynamic soil properties $\left(G / G_{\max }\right.$ variation and D with Y) both for sandy and clayey soils (Ishibashi and Zhang 1993).

Estimation of the shear modulus and damping curves may be obtained from laboratory measurements a soil samples or derived from empirical models based on soil type and other variables (Kottke and Rathje 2009). There are some empirical model developed by Richard et al. 1970, Seed and Idriss 1970, Hardin and Drnevich 1972, Zen et al. 1978, GEl 1983, Seed et al. 1986, Sun et al. 1988, GeoMatrix 1990, Vaucetic and Dobry 1991, EPRI 1993, Darendeli and Stokoe 2001, etc. (Jafarian, Haddad and Javdanian 2014, Kottke and Rathje 2009, Zhang, Andrus and Juang 2005) The main factors that influence $G / G_{\max }$ and $D$ are: confining pressure $\left(\sigma_{m}^{\prime}\right)$ plasticity index $(P I)$, over consolidation ratio (OCR), frequency (f) and number of cycles of loading (N) (Bahar, Saci, Louadj and Vicens 2012).

In general, the evaluation of the dynamic soil properties are made by means of "in situ" tests (down-hole, up-hole, cross-hole, dynamic penetration, spectral analysis of surface waves) or laboratory tests (resonant column, cyclic simple shear, cyclic torsional shear and cyclic triaxial). 
In this paper, for the analysis of the seismic site response it was used the characteristic curves proposed by Idriss (1990) for sands and clays. The carried out simulations took into consideration physical and mechanical characteristics of the Romanian's soils. The numerical simulations were performed by using Strata software.

Due to the variation of the shear deformation and seismic motion intensity, both for the cohesive and cohesionless soils, for the studied soil deposit it was performed an equivalent linear site response analysis.

According to the soil type and stratigraphy, it was introduced in the program, as input values, a number of average characteristics of the soil deposit depending on its physical state, highlighted in table 1.

The input motions defined in the program are represented by the accelerograms of 1977, 1986 and 1990 earthquake, recorded by the seismic station of INCERC Bucharest. In the program it was considered those accelerograms recorded on the $\mathrm{N}-\mathrm{S}$ direction of the earthquake motion. In table 2 the main characteristics of the accelerograms defined in the program are presented. The location of the input motion is considered to be at the top of the bedrock.

Seed and Idriss (1970) introduced for the first time the equivalent-linear analysis approach, being a referenced point for the subsequent researches (Matosovic and Hashash 2012).

In order to evaluate the soils from the site response analysis point of view, it has been considered, as output data, for both cohesive and cohesionless soil deposit, the following results after running Strata software: damping ratio, shear modulus profile, spectral ratio, accelerations response spectrum at the surface and at the bedrock.

In the graphic representations it was used the following notations: case 1 for the 1977 acceleration data, case 2 for 1986 acceleration data and case 3 for 1990 acceleration data.

\begin{tabular}{c|c|c|c|c}
\hline \multirow{2}{*}{$\begin{array}{c}\text { Depth } \\
{[\mathrm{m}]}\end{array}$} & \multicolumn{2}{|c|}{$\begin{array}{c}\text { Cohesionless soil } \\
\text { (sand) }\end{array}$} & \multicolumn{2}{c}{ Cohesive soil (clay) } \\
\cline { 2 - 5 } & $\begin{array}{c}\text { Unit weight } \\
\mathrm{\gamma}\left[\mathrm{kN} / \mathrm{m}^{3}\right]\end{array}$ & $\begin{array}{c}\mathrm{V}_{\mathrm{s}} \\
{[\mathrm{m} / \mathrm{s}]}\end{array}$ & $\begin{array}{c}\text { Unit weight } \\
\mathrm{r}\left[\mathrm{kN} / \mathrm{m}^{3}\right]\end{array}$ & $\begin{array}{c}\mathrm{V}_{\mathrm{s}} \\
{[\mathrm{m} / \mathrm{s}]}\end{array}$ \\
\hline $0-5$ & 17.5 & 50 & 18.5 & 150 \\
\hline $5-30$ & 18.0 & 100 & 18.5 & 200 \\
\hline $30-50$ & 18.0 & 150 & 19.0 & 300 \\
\hline $50-70$ & 18.5 & 200 & 19.5 & 400 \\
\hline Bedrock & 22.0 & 750 & 22.0 & 750 \\
\hline
\end{tabular}

\begin{tabular}{c|c|c|c}
\hline $\begin{array}{c}\text { Earthquake } \\
\text { year }\end{array}$ & $\begin{array}{c}\text { PGA } \\
\left(\mathrm{m} / \mathrm{s}^{2}\right)\end{array}$ & $\begin{array}{c}\text { PGV } \\
(\mathrm{m} / \mathrm{s})\end{array}$ & $\begin{array}{c}\mathrm{PGD} \\
(\mathrm{m})\end{array}$ \\
\hline 4 martie 1977 & 1.949 & 0.719 & 1.631 \\
\hline 31 august 1986 & 0.838 & 0.075 & 0.014 \\
\hline 30 mai 1990 & 0.662 & 0.064 & 0.011 \\
\hline
\end{tabular}
and 1990 on N-S direction

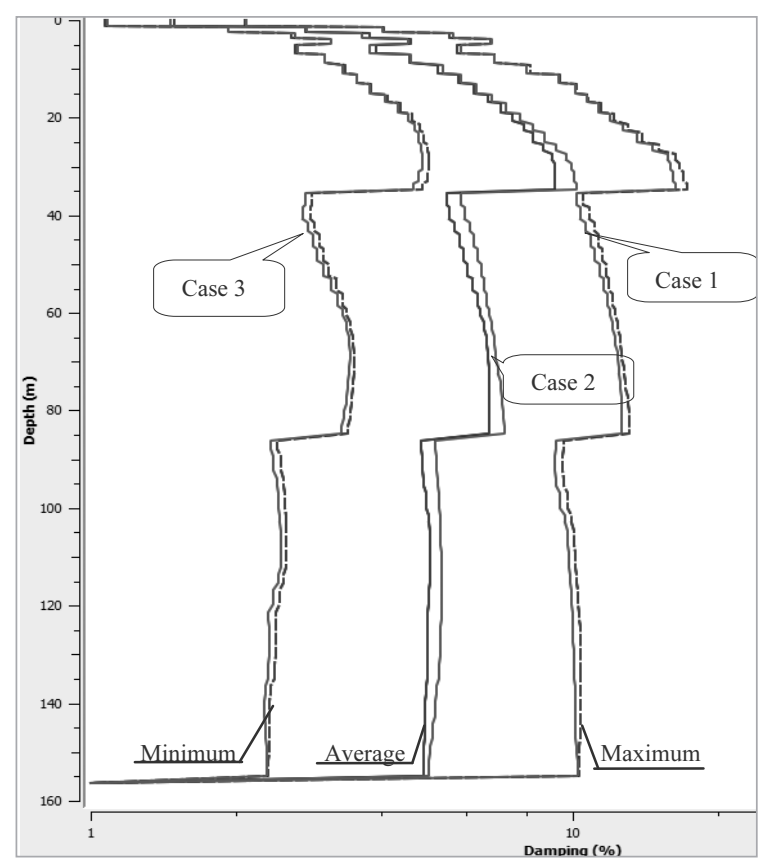

Table 2

Characteristics values of the accelerograms recorded in 1977, 1986

Table 1

Minimum element thicknesses $(\mathrm{mm})$ for typical fire resistance periods (minutes) (NSAl, 2005)

Results and discussions

\section{Fig. 1}

Variation of damping ratio (D) under different earthquake excitations (cohesive soil) 


\section{Results obtained for the cohesive soil deposit}

According to the Idriss (1990) empirical model for clays it was possible to evaluate, using Strata software, the degradation of the shear modulus and damping ratio curves for a cohesive deposit soil, presented in Fig. 1 and Fig. 2.

It can be noted that, the most unfavorable behavior of the shear modulus and damping ratio (Fig. 1 and Fig. 2) is the one in which it was used as input ground motion 1977 earthquake accelerogram.

Furthermore, in Fig. 3 it can be observed that the degradation curve of the cohesive soil is bigger in the first case than in the others, a fact that confirms the statements mentioned above.

Fig. 2

Variation of damping ratio (D) under different earthquake excitations (cohesive soil)

Fig. 3

Maximum shear-strain for different earthquake excitations (cohesive soil)
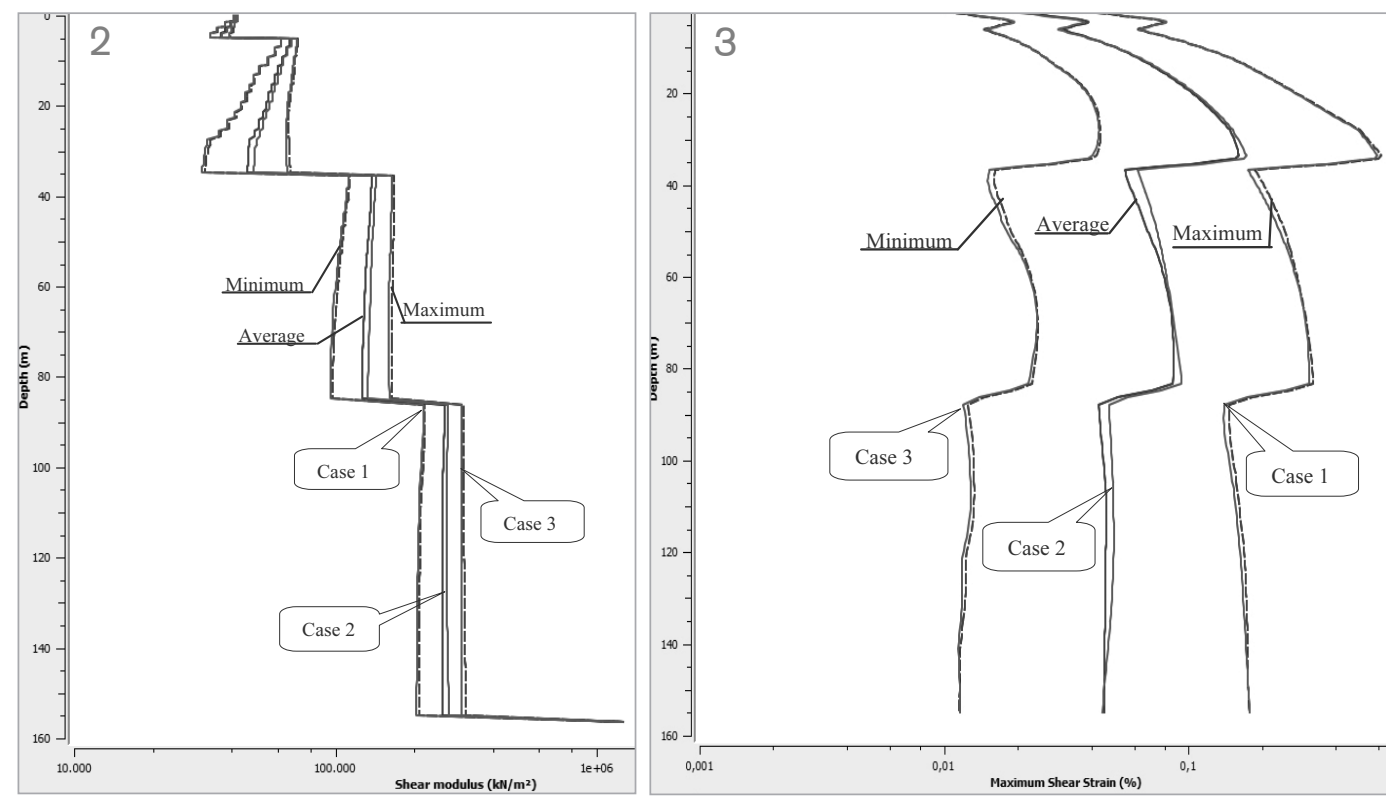

Fig. 4

Spectral ratio between surface and bedrock (cohesive soil)

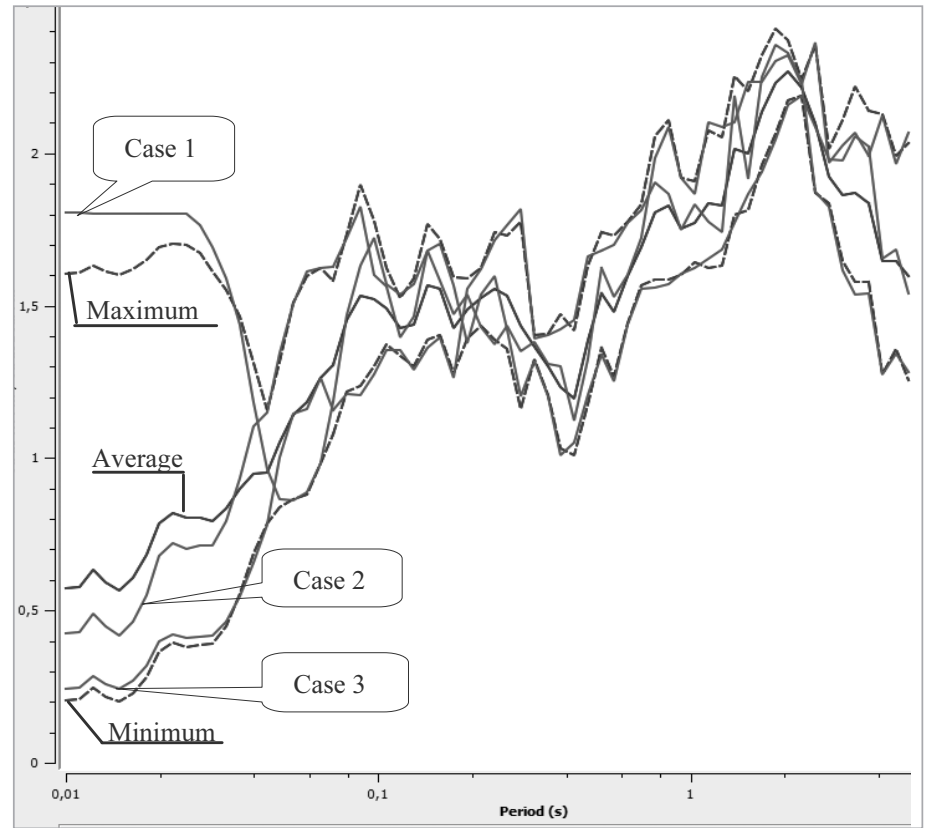

The median value of shear-strain is equal with $0.046 \%$ at $100 \mathrm{~m}$ depth.

Fig. 4 shows spectral ratio between surface and bedrock for the considered layer of cohesive soil deposit in relation with the maximum, minimum and average values.

The main parameters that influence the site response are input ground motions, wave velocity profile and material nonlinearity (Matosovic and Hashash 2012, Graizer 2011, Luke and Liu 2008). 
These parameters are expressed by the acceleration response spectrum In order to determine a site response analysis it is necessary to determine the acceleration response spectrum at the surface and at the bedrock. Thus, in Fig. 5 and Fig. 6 the acceleration response spectrum for the three considered cases are compared.

The maximum acceleration that corresponds to the first case, having the value $A S_{\text {max }}=1.043 \mathrm{~g}$, compared to the second and third case, where $\mathrm{AS}_{\max }$ is $0.466 \mathrm{~g}$ and $0.387 \mathrm{~g}$, respectively. These values are specific to the acceleration response spectrum at the surface (Fig. 5).

The maximum values of acceleration response spectrum at the bedrock highlighted in Fig. 6 are: $A S_{\max }=0.631 \mathrm{~g}$ for 1977 earthquake, $A S_{\max }=0.409 \mathrm{~g}$, for 1986 and $A S_{\max }=0.408 \mathrm{~g}$ for 1990 .
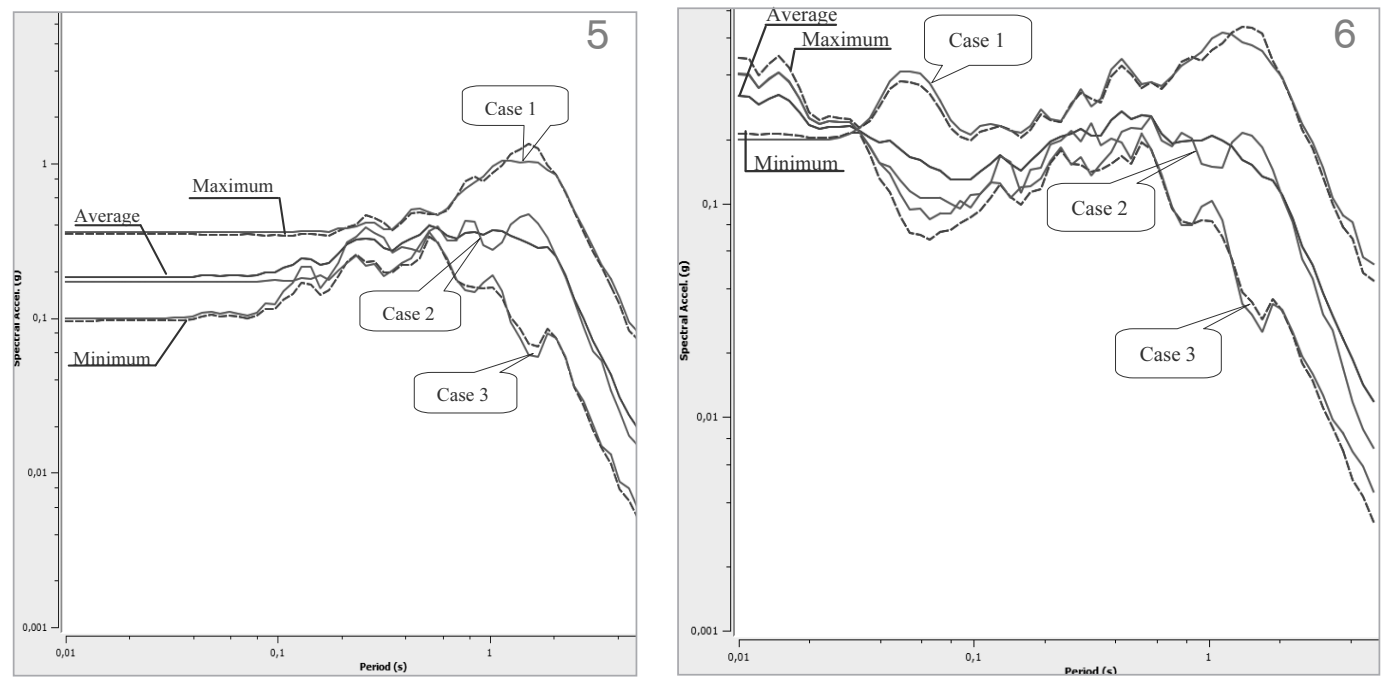

\section{Results obtained for the cohesionless deposit}

As in the first case, an evaluation of the shear modulus and damping ratio curves was done, but in this situation for a cohesionless soil deposit, using the Idriss (1990) empirical model for sands.

According to the Fig. 7 and Fig. 8, also for the non-cohesive soil, it was observed that the most
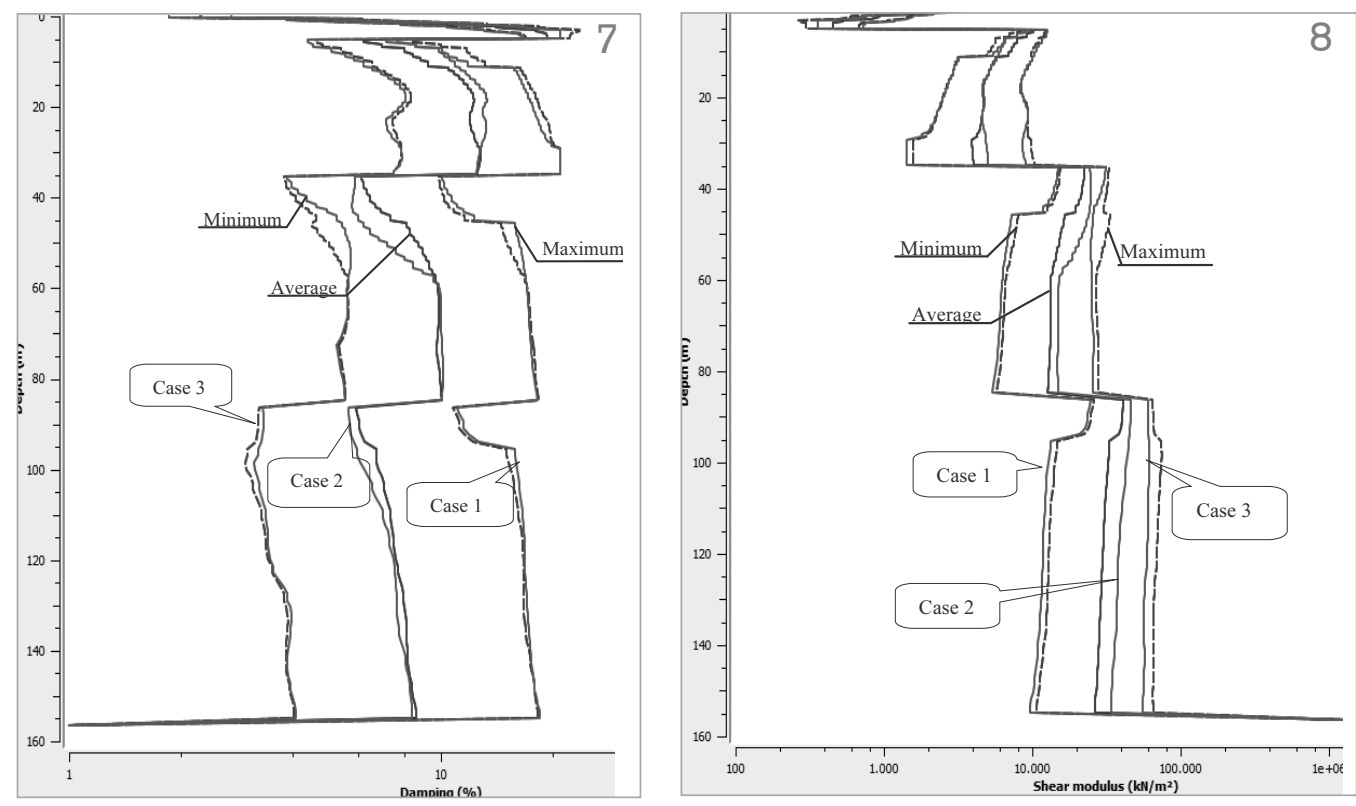

Fig. 5

Acceleration response spectrum at the surface (cohesive soil)

Fig. 6

Acceleration response spectrum at the bedrock (cohesive soil)

Fig. 7

Damping ratio (D) profile under different earthquake excitations (cohesionless soil)

Fig. 8

Degradation of shear modulus (G) under different earthquake excitations (cohesionless soil) 
unfavorable results correspond to the first case.

In the first case, spectral ratio has a minimum variation in relation with the average value of the three considered cases (Fig. 9).

The median value of shear-strain is equal with $0.108 \%$ at $100 \mathrm{~m}$ depth (Fig. 10).

Fig. 9

Spectral ratio between surface and bedrock (cohesionless soil)

Fig. 10

Maximum shear-strain for different earthquake excitations (cohesionless soil)

Fig. 11

Acceleration response spectrum at the surface (cohesionless soil)

Fig. 12

Acceleration response spectrum at the bedrock (cohesionless soil)
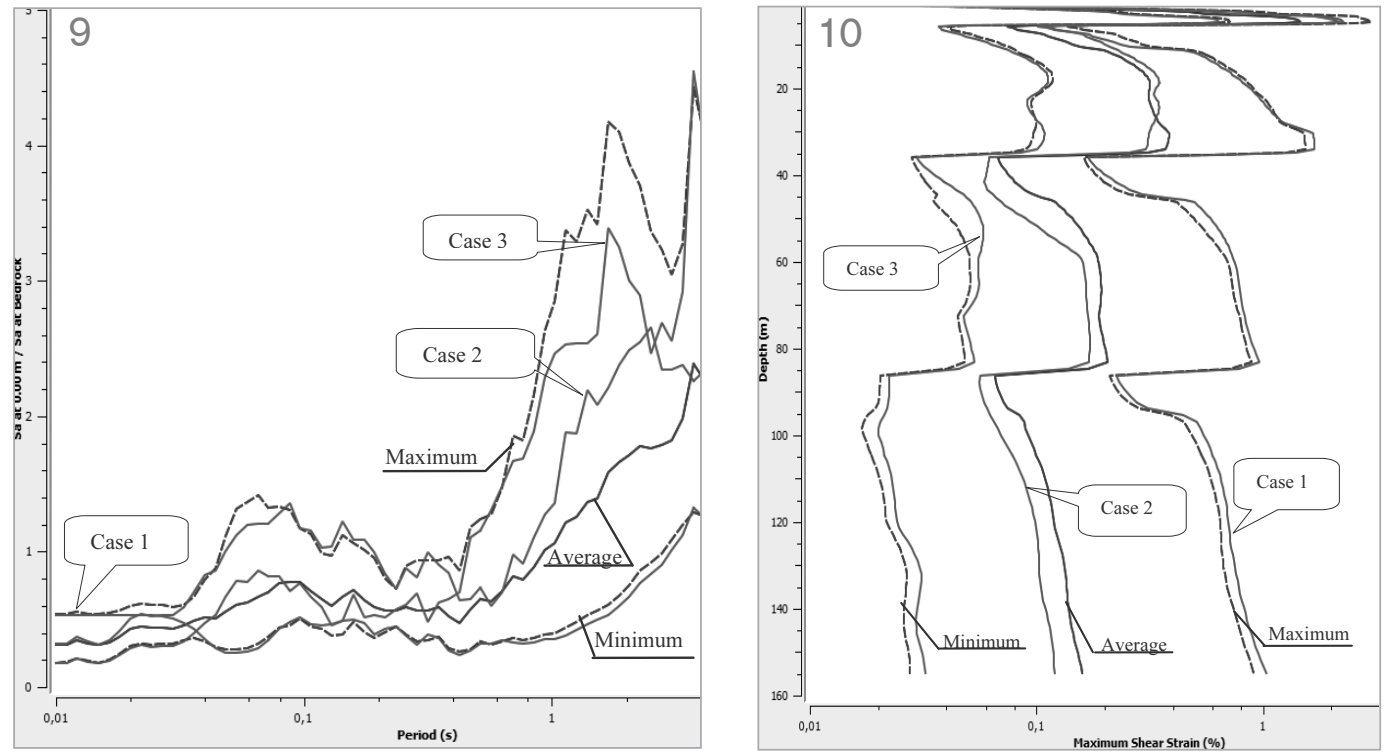

Compared to the cohesive soil deposit, the maximum value of acceleration response spectrum for non-cohesive soil corresponds to the second case, having the value of $\mathrm{AS}_{\max }=0.434 \mathrm{~g}$ (Fig. 11). The values for the second case and third case are $0.278 \mathrm{~g}$ and $0.246 \mathrm{~g}$, respectively. It can be also noticed that the values of spectral accelerations are lower compared to the cohesive soil.

The maximum values of acceleration response spectrum at the bedrock highlighted in Fig. 12 are: $A S_{\max }=0.626 \mathrm{~g}$ for 1977 earthquake, $A S_{\max }=0.408 \mathrm{~g}$, for 1986 and $A S_{\max }=0.411 \mathrm{~g}$ for 1990 .
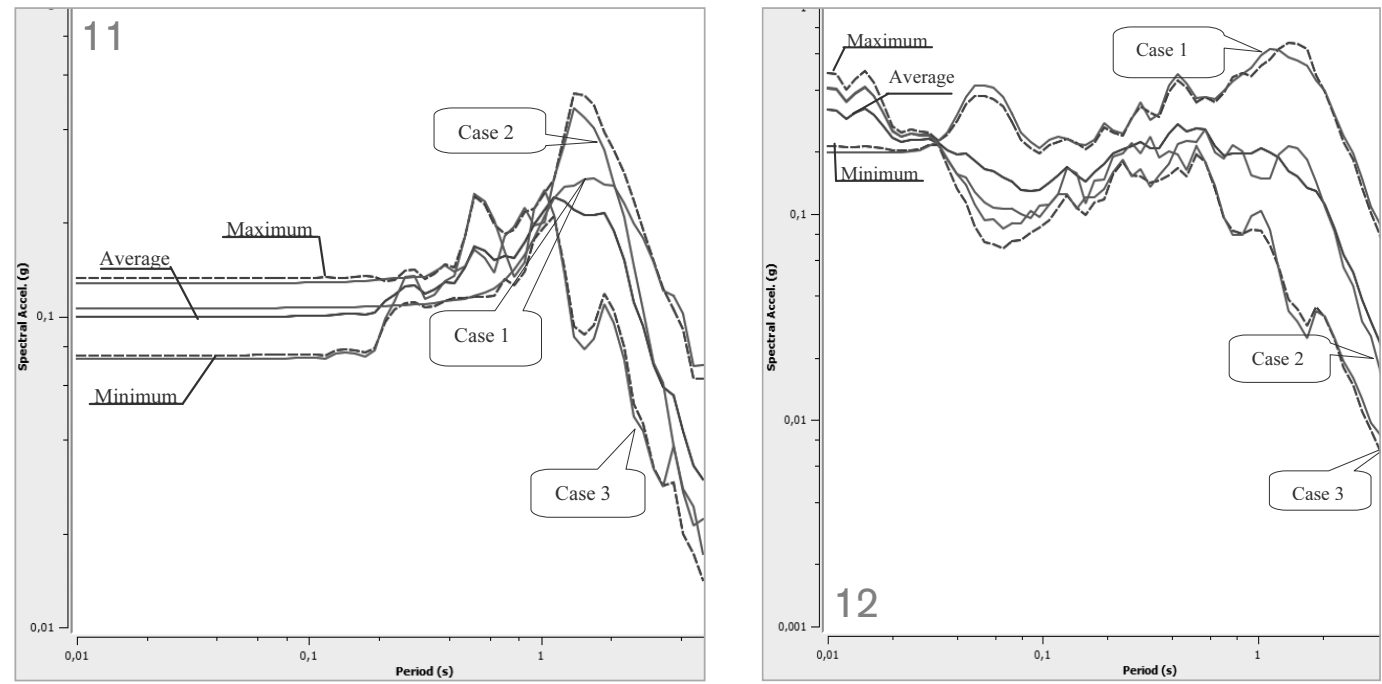

In Fig. 13, Fig. 14 and Fig. 15 the acceleration data recorded at the surface with the software Strata for a cohesive soil deposit are represented. 
In Fig. 16, Fig. 17 and Fig. 18 the acceleration data recorded at the surface with the software Strata for a cohesionless soil deposit are represented.
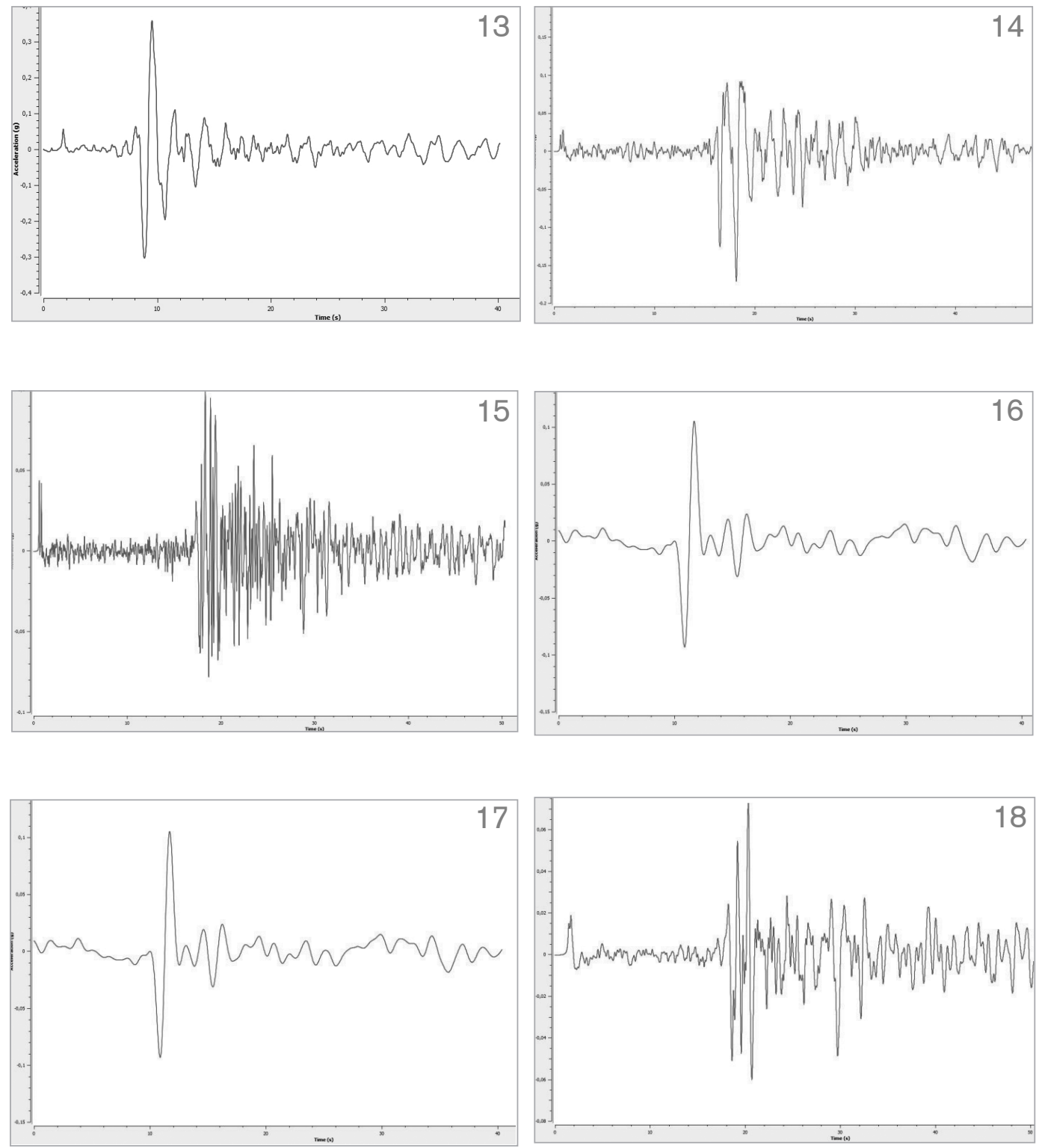

Using the acceleration data recorded on Romania territory during 1977, 1986 and 1990 earthquake, empirical model proposed by Idriss (1990) and Strata software we can make predictions on the dynamic behavior for different sites.

From the results obtained, using the program Strata for a clayey and sandy soil deposit, it was found that seismic propagation of the waves is directly related to the type of the earth, and its physical and mechanical characteristics. Also, the type of soil directly influences spectral ratio and acceleration response spectrum.

This work presents a preliminary study on evaluation of the shear modulus and damping ratio curves. For future researches we will intend to analyze an equivalent-linear modeling of site response based on cohesive soil deposit such as Bahlui clay.
Fig. 13

Acceleration of 4 March, 1977 earthquake at the surface, direction NS -

Strata (cohesive soil)

Fig. 14

Acceleration of 31 August, 1986 earthquake at the surface, direction NS Strata (cohesive soil)

Fig. 15

Acceleration of 30 may, 1990 earthquake at the surface direction NS Strata (cohesive soil)

Fig. 16

Acceleration of 4 March, 1977 earthquake at the surface, direction NS (cohesionless soil)

Fig. 17

Acceleration of 31 August, 1986 earthquake at the surface, direction NS (cohesionless soil)

Fig. 18 Acceleration of 30 may, 1990 earthquake at the surface direction NS (cohesionless soil)

\section{Conclusions}




\section{Acknow- ledgment} The authors would like to thank to Ellen M. Rathje and Albert Kottke, for free use of Strata software.

\section{References}

Balan S., and others 1983. Cutremurul de pământ din România de la 4 martie 1977 [The Romania earthquake of 4 March 1977].Editura Academiei.

Bahar R., Saci L., Louadj S., Vicens E. 2012. Numerical evaluation of shear modulus degradation and damping curves of Algerian soils using geophysical tests. In: $15^{\text {th }}$ World Conference on Earthquake Engineering. Lisbon, Portugal.

Eurocode 8 1998: Design of structures for earthquake resistance. Part 1: General rules, seismic actions and rules for buildings.

Graizer V. 2011. Treasure island geotechnical array case study for site response analysis. In: $4^{\text {th }}$ IASPEI/ IAEE International Symposium: Effects of Surface Geology on Seismic Motion. California, United States of America.

Incerc București, 2004. Available at: http://www. incerc2004.ro/accelerograme.htm (accessed 10 March 2014).

Ishibashi I., Zhang X. 1993. Unified dynamic shear modulus and damping ratio of sand and clay. In: Soils and Foundations, Japan. 1993, Vol. 33, 182191.

Jafarian Y., Haddad A., Javdanian H. 2014. Predictive model for normalized shear modulus of cohesive soils. In: Acta Geodynamica et Geomaterial, Vol. 11, 1(173), 89-100.

Luke B., Liu Y. 2008. Site response zones and shortperiod earthquake ground motion projections for Las Vegas Basin. In: Journal of Earth System Science, 2(117), 757-772. http://dx.doi.org/10.1007/ s12040-008-0059-1
Mahin S., (2008). Sustainable design considerations in earthquake engineering. In: The $14^{\text {th }}$ Woeld Conference on Earthquake Engineering, Beijing, China.

Matosovic N., Hashash Y. 2012. Practices and procedures for site-specific evaluations of earthquake ground motions. Available at: http:// www.national-academies.org/trb/bookstore.

Pomonis A., Coburn A.W., Ledbetter S. (1990). The Vrancea Romania earthquakes of 30-31 May 1990. A Field Report by E.E.F.I.T.

Rathje E. M., Kottke A. 2013. Strata. Available at: https://nees.org/resources/strata.

Sokolov V., Boese M., Wenyel F. 2008. Shakemap methodology based on Fourier amplitude spectra and its application for the case of Vrancea earthquakes in Romania. In: The $14^{\text {th Woeld }}$ Conference on Earthquake Engineering, Beijing, China.

Vlad I., Vlad M., 2008. Behavior of dwellings during strong earthquakes in Romania. In: The $14^{\text {th }}$ World Conference on Earthquake Engineering, Beijing, China.

Kottke A., Rathje E. 2013. Technical Manual for Strata. PEER Report, Universitz of California, Berkeley.

Zhang J., Andrus R. D., Juang C.H. 2005. Normalized shear modulus and material damping ratio relationship. In: Journal of Geotechnical and Geoenvironmental Engineering 4(453), 453464 . http://dx.doi.org/10.1061/(ASCE)10900241(2005)131:4(453)

About the authors

\section{ANA NICUȚĂ}

\section{Head of Department}

Gheorghe Asachi" Technical University Transportation Infrastructure and Foundations Department

\section{Main research area}

Geotechnical engineering, foundations under special conditions, soil dynamics

\section{Address}

43 D. Mangeron, 700050 lasi, Romania

Tel. +40740823522

E-mail: nicutaana@yahoo.com

\section{ALEXANDRA ALISA GĂINĂ}

\section{PhD student}

Gheorghe Asachi" Technical University Transportation Infrastructure and Foundations Department

\section{Main research area}

Geotechnical engineering and soil dynamics

Address

43 D. Mangeron, 700050 lasi, Romania

Tel. +40747877217

E-mail: alisa.gaina@yahoo.com 